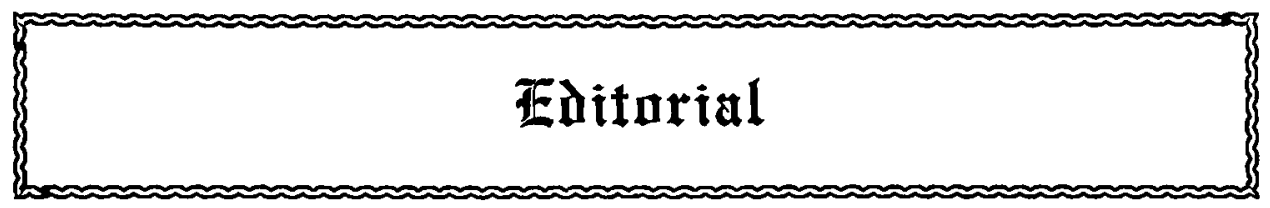

Ernf:st C. Marshall, Acting Editor 63 Clinton Building, Columbus. Ohio

\title{
THE CONVENTION.
}

$\mathrm{T}$ $\mathrm{HE} \mathrm{A.} \mathrm{Ph.} \mathrm{A.} \mathrm{Convention} \mathrm{for} 1914$ is a thing of the past; its action is accomplished and its mission completed,-no, not completed, for the effects of its work will be felt for years to come in revivifying and renewing the soul of pharmacy,--its science, its erudition, its technique,-all that bestows upon pharmacy true dignity and honor.

For sixty-two years the Association has held these things in charge as a precious heritage. In every honorable and dignified way it has striven to uplift and dignify the name of Pharmacist; it has resisted the sordid spread of commercialism within the profession, and has labored to keep its shield clean and bright when sullied by the cankering rust of mercenariness, Thaler-lust, and all that tends to the degradation, the lowering of mentality and character to any class or to any man in which these things become the predominant passion.

High above the bitter strife for existence, the selfish war of the world, it has held aloft its proud banner inscribed A. Ph. A., which might well be read, Ars, Pharo. Abante,-art, beacon-light, advancement, and has steadily pursued its way undisturbed by the forces of evil, which, surrounding our profession, seek to degrade it to the lowest levels; to make it simply the means of the sordid accumulation of pelf. forgetful, if not ignorant, of those noble spirits who, despising the dross of life, have given to the profession its dignity, its character, its very life. Ignorant or forgetful of Paracelsus, Agricola, Sylvius, Boyle, Priestly, Lavoissier, and Scheele, and the hosts of others who have gone to their graves almost "unwept, unhonored and unsung," while ennobling the calling the profession of the Pharmacist, and to whose efforts they are indebted for all the respect the profession of Pharmacy enjoys to-day.

In this world the forces of good and evil are always at war. Nobility is arrayed against rascality, virtue against vice; generosity against greed, and against all the beneficent forces of nature, are arrayed the evils of canker, rust, blight and decay. And so with Pharmacy:-men have taken its livery,- the livery of heaven,- to serve the devil of Mammon in. Around it and even within its ranks are those who know nothing and who care less of its history, its nobility, its character and its ideals and who would barter most willingly its honored name for a mess af pottage. To all these mercenary spirits the A. Ph. A has turned a deaf ear and has held its rudder true to the pole-star of honor, of character, of selfrespect, refusing to lower its unsullied flag or to allow its pure folds to be dragged in the foul pools of money-grubbing.

All honor to those who established the Association upon such memories and 
such traditions; who used for its foundation this Ehrenbreitstein, of character; all honor to those who have so carefully and lovingly treasured its name and its reputation, and all honor to its rank and file, who, by their earnest support have made the A. Ph. A. the guiding-light of American Pharmacy and a beacon for the world.

God give them strength for their work, that there may come to Pharmacy the place and that distinction so long denied, so foully threatened, but which its service to the world,-a service of usefulness and honor justly entitles it.

The Convention was a distinct success in every particular. From the opening of the first session until the close of the meeting the feeling expressed by all in attendance was that it was one of great profit to every member present and to the whole profession of Pharmacy.

The arrangements made by the Local Committee were carried out in a manner beyond all praise. Every detail looking to the prompt and careful conduct of the Convention and the enjoyment and comfort of each individual member was carefully observed and the vote of thanks bestowed upon the Local Secretary and the Local Committee by the Convention at its last session was one which was thoroughly well deserved. It is much to be hoped that the routine of their work may be put in print for the guidance of future Local Committees, who too often enter upon their work full of zeal to do their best, but without any well-tried and perfectly-outlined plan of their duties, to act as a guide for them in their new and unusual work.

The experience of a local committee whose work has been so distinctly a success as that of the Detroit Committee would be most valuable to that of all future Local Committees.

E. C. Marshall.

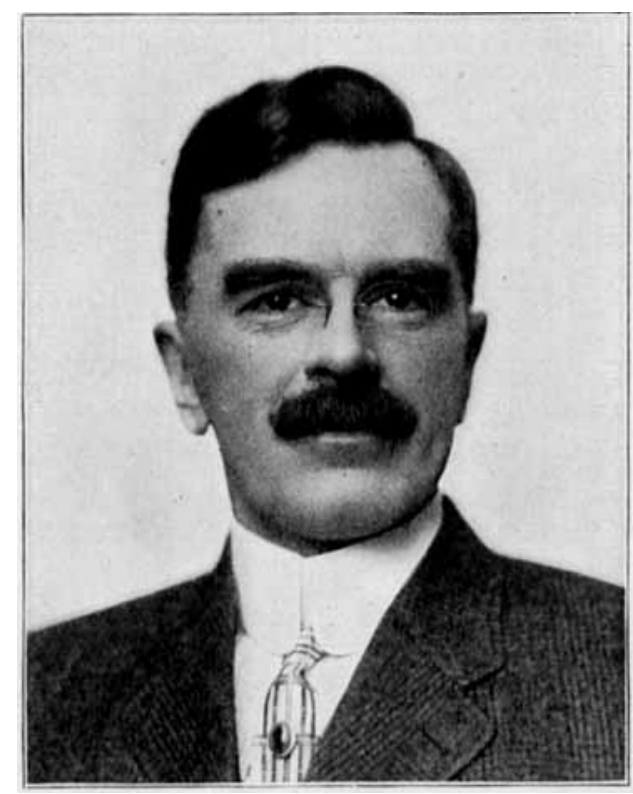

H. B. MASON

CHAIRMAN SECTION ON COMMERCIAL INTERESTS. 